\title{
PENERAPAN GEOGEBRA UNTUK MENINGKATKAN KEMAMPUAN PEMECAHAN MASALAH MATEMATIS MAHASISWA PROGRAM STUDI PENDIDIKAN MATEMATIKA UNIVERSITAS SURYAKANCANA
}

\author{
Ari Septian \\ Universitas Suryakancana \\ ariseptian@unsur.ac.id
}

\begin{abstract}
ABSTRAK
Kalkulus II merupakan materi yang harus dipahami oleh mahasiswa sebagai dasar untuk mengajar di sekolah. Integral yang menjadi pokok pembahasan pada mata kuliah kalkulus II menjadi fokus utama. Mahasiswa masih mengalami kesulitan dalam menentukan luas daerah dan volume benda putar pada materi integral dengan menggunakan fungsi-fungsi yang bervariasi. Oleh karena itu perlu suatu cara baru berbasis teknologi agar mahasiswa lebih tertarik dan tentunya paham materi kalkulus II dengan menggunakan software GeoGebra. Jenis penelitian menggunakan eksperimen kuasi. Subjek penelitian ini adalah mahasiswa tingkat 2 semester 4 tahun akademik 2015-2016 sebanyak dua kelas, kelas B sebagai kelas eksperimen dan kelas A sebagai kelas kontrol. Desain penelitian ini menggunakan desain nonequivalent control group design. Pengumpulan data dilakukan dengan menggunakan instrumen tes berupa soal uraian dan non tes berupa angket skala sikap. Hasilnya, peningkatan kemampuan pemecahan masalah matematis mahasiswa yang menerapkan GeoGebra lebih baik daripada mahasiswa yang menggunakan pembelajaran ekspositori dan sikap mahasiswa terhadap penerapan GeoGebra positif.
\end{abstract}

Kata Kunci : GeoGebra, Pemecahan Masalah, Kalkulus II

\section{PENDAHULUAN}

Perguruan Tinggi merupakan pelaksana pendidikan sekaligus ujung tombak pelaksana tujuan pendidikan. Program Studi Pendidikan Matematika sebagai pencetak calon guru masa depan diharapkan dapat mereformasi kebiasaan yang dilakukan, hal ini sesuai dengan perkembangan zaman yang mengarah kepada dunia teknologi dengan tujuan agar mahasiswa menjadi guru yang menguasai kemampuan pedagogik, ilmu matematika, dan iptek.

Perkembangan ilmu pengetahuan dan teknologi seiring berjalannya waktu telah mengubah kebiasaan lama menjadi kebiasaan baru. Dalam dunia pendidikan khususnya, kebiasaan mahasiswa dalam menggunakan gadget-gadget canggih telah mengubah gaya 
belajar mereka yang tergantung pada internet. Untuk mencari informasi terkait mata kuliah tertentu, mahasiswa tinggal mencari melalui browser atau mesin pencari.

Hal ini mengakibatkan dosen harus lebih kreatif dalam mencari dan membuat bahan ajar baik berbentuk buku, ebook, maupun aplikasi pembelajaran. Penguasaan teknologi sudah menjadi lumrah dewasa ini dalam perkembangan dunia pendidikan. Berbagai penggunaan aplikasi-aplikasi pembelajaran matematika sudah barang tentu menjadi hal yang biasa bagi dosen dan mahasiswa.

Teknologi yang banyak digunakan dalam pembelajaran matematika adalah komputer. Salah satu perangkat lunak komputer yang dapat dimanfaatkan dalam pembelajaran matematika adalah perangkat lunak GeoGebra. Dengan beragam fasiltas yang dimiliki, GeoGebra dapat dimanfaatkan sebagai media pembelajaran matematika untuk mendemonstrasikan atau memvisualisasikan konsep-konsep matematis serta sebagai alat bantu untuk mengkonstruksi konsep-konsep matematis (Mahmudi, 2011).

GeoGebra dikembangkan oleh Markus Hohenwarter pada tahun 2001. GeoGebra adalah perangkat lunak matematika gratis dan multi-platform yang dinamis untuk semua tingkat pendidikan yang menggabungkan geometri, aljabar, tabel, grafik, statistik dan kalkulus dalam satu paket yang mudah digunakan. Perangkat lunak ini telah menerima beberapa penghargaan perangkat lunak pendidikan di Eropa dan Amerika Serikat. Beberapa kelebihan GeoGebra antara lain : 1) grafik, aljabar dan tabel terhubung dan sangat dinamis; 2) Mudah digunakan namun banyak fitur canggih, 3) authoring tool (alat pengubah) untuk membuat bahan pembelajaran interaktif sebagai halaman web; 4) tersedia dalam banyak bahasa untuk jutaan pengguna kami di seluruh dunia; dan 5) Perangkat lunak open source yang tersedia secara bebas untuk pengguna non-komersial (http://www.GeoGebra.org/cms/in/info).

Menurut Hohenwarter (Mahmudi, 2011), program GeoGebra sangat bermanfaat bagi guru maupun siswa. Tidak sebagaimana pada penggunaan software komersial yang biasanya hanya bisa dimanfaatkan di sekolah, GeoGebra dapat diinstal pada komputer pribadi dan dimanfaatkan kapan dan di manapun oleh siswa maupun guru. Bagi guru, GeoGebra menawarkan kesempatan yang efektif untuk mengkreasi lingkungan belajar online interaktif yang memungkinkan siswa mengeksplorasi berbagai konsep-konsep matematis. Sejumlah penelitian menunjukkan bahwa GeoGebra dapat mendorong proses 
penemuan dan eksperimentasi siswa di kelas. Fitur-fitur visualisasinya dapat secara efektif membantu siswa dalam mengajukan berbagai konjektur matematis (Mahmudi, 2011).

Perangkat lunak ini dapat digunakan dengan siswa berusia 10 sampai 18, dimulai dengan konstruksi sederhana sampai dengan integrasi fungsi. Siswa dapat mengeksplorasi matematika sendiri atau dalam kelompok. Guru berperan sebagai fasilitator ketika bantuan diperlukan. Hasil eksperimen siswa dengan GeoGebra harus menjadi dasar untuk diskusi di kelas. Hal ini memberikan guru lebih banyak waktu untuk berkonsentrasi pada ide-ide dasar dan penalaran matematika (Hohenwarter dan Fuchs, 2004). Pemanfaatan GeoGebra ini dapat pula digunakan dalam pembelajaran matematika pada mahasiswa. Karena materi dalam GeoGebra dapat dikembangkan secara mandiri dan dinamis. GeoGebra membantu mahasiswa dalam mengembangkan kemampuan matematis mahasiswa.

Kemampuan matematis yang akan diteliti dalam penelitian ini yaitu kemampuan pemecahan masalah matematis sebagai bagian dari kemampuan matematis merupakan hal penting sehingga mahasiswa dapat menyesuaikan dengan tuntutan dari masyarakat serta perkembangan teknologi informasi yang saat ini semakin pesat.

Oleh karena itu, peneliti ingin mengetahui dan menelaah sejauh mana kemampuan pemecahan masalah matematis mahasiswa melalui penelitian yang berjudul "Penerapan GeoGebra untuk Meningkatkan Kemampuan Pemecahan Masalah Matematis Mahasiswa Program Studi Pendidikan Matematika Universitas Suryakancana”.

Berdasarkan latar belakang masalah diatas, maka permasalahan tersebut dijabarkan sebagai berikut :

a. Apakah peningkatan kemampuan pemecahan masalah mahasiswa yang menerapkan Geogebra lebih baik daripada yang menggunakan pembelajaran ekspositori ?

b. Bagaimana sikap mahasiswa terhadap penerapan GeoGebra dalam perkuliahan di Program Studi Pendidikan Matematika Universitas Suryakancana?

\section{METODOLOGI PENELITIAN}

Metode penelitian yang digunakan dalam penelitian ini adalah Quasy Experimental (Arikunto, 2009 : 209). Quasy-eksperimental digunakan karena tidak semua variabel dapat dikontrol. Desain penelitian kuasi eksperimen yang digunakan dalam penelitian ini berbentuk Nonequivalent Control Group Design yang melibatkan dua kelompok peserta 
didik, yaitu kelas kontrol dan kelas eksperimen. Perbedaan antara dua kelompok tersebut adalah perlakuan dalam proses pembelajaran. Pada kelompok eksperimen proses belajar mengajarnya memperoleh perlakuan dengan menerapkan GeoGebra, sedangkan pada kelompok kontrol proses belajar mengajarnya memperoleh perlakuan dengan pembelajaran ekspositori.

Populasi pada penelitian ini adalah seluruh mahasiswa Program Studi Pendidikan Matematika tingkat 2 semester 4 tahun akademik 2015-2016 di Universitas Suryakancana Cianjur. Sebagai kelas kontrol (Kelas 2A) dan kelas eksperimen (Kelas 2B). Teknik pengambilan sampelnya menggunakan purposive sampling, karena pengambilan anggota sampel dilakukan dengan pertimbangan tertentu (Sugiyono, 2007). Pengambilan sampel kelas ini ditentukan oleh perguruan tinggi.

Instrumen dalam penelitian ini terdiri dari tes dan non tes. Tes dalam penelitian ini menggunakan pretes dan postes kemampuan pemecahan masalah matematis, sedangkan yang termasuk instrumen non-tes adalah skala sikap mahasiswa terhadap penerapan GeoGebra. Tes yang digunakan dalam penelitian ini ditujukan untuk mengetahui kemampuan pemecahan masalah matematis mahasiswa. Mengacu pada metode dan desain penelitian tes dilakukan sebanyak dua kali yakni pretes dan postes.

Instrumen yang akan diberikan kepada mahasiswa terlebih dahulu diujicobakan untuk mengetahui validitas dan reliabilitasnya. Untuk kemudian dari hasil uji coba setiap butir soal dianalisis untuk mengetahui tingkat kesukaran dan daya pembedanya. Uji coba dilakukan pada mahasiswa Program Studi Pendidikan Matematika tingkat 3 yang sudah pernah memperoleh mata kuliah kalkulus II. Setelah uji coba dilakukan pada kelas tersebut selanjutnya dilakukan langkah - langkah analisis untuk mengetahui validitas, reliabilitas, daya pembeda dan tingkat kesukaran. Dari hasil uji coba yang diolah menggunakan Software Anates V4, dapat disimpulkan bahwa seluruh butir soal yang diujicobakan valid dan reliabel sehingga dapat digunakan sebagai instrumen tes dalam penelitian ini.

Dalam penelitian ini angket disusun dengan menggunakan skala sikap model Likert. Dimana pernyataan itu terbagi atas dua kategori, yaitu pernyataan positif dan negatif. Skala sikap ini terdiri dari tiga aspek, yaitu sikap mahasiswa terhadap pembelajaran matematika, sikap mahasiswa terhadap penerapan GeoGebra, dan sikap mahasiswa terhadap kemampuan pemecahan masalah matematis. Setiap pernyataan dalam 
angket merupakan pertanyaan tertutup sehingga responden hanya memilih alternatif jawaban yang sesuai yaitu : sangat setuju (SS), setuju (S), Netral (N), tidak setuju (TS), atau sangat tidak setuju (STS).

Pengolahan data dalam penelitian ini disesuaikan dengan keperluan jenis analisis yang akan digunakan, untuk tes kemampuan pemecahan masalah matematis mahasiswa dinilai dengan skor rubrik 1-4. Analisis ini dilakukan untuk setiap kelompok data sesuai dengan masalahnya. Skala sikap yang digunakan adalah skala sikap model Likert. Jawaban mahasiswa terhadap penerapan GeoGebra dinilai dengan menghitung frekuensi jawaban mahasiswa dalam bentuk nilai mutlak dan nilai persentase.

Data hasil penelitian yang diperoleh berupa data kuantitatif dan data kualitatif. Data kuantitatif yaitu data yang diperoleh dari pretes dan postes. Sedangkan data kualitatif yaitu data yang diperoleh dari hasil skala sikap mahasiswa.

\section{HASIL DAN PEMBAHASAN}

Pada hasil penelitian ini akan dikemukakan mengenai analisis data hasil pretest, posttest, dan angket skala sikap.

\section{Pretest Kemampuan Pemecahan masalah matematis Mahasiswa}

Tujuan diberikan pretest adalah untuk mengetahui apakah kedua kelas memiliki kemampuan pemecahan masalah matematis awal yang sama atau tidak. Berikut ini disajikan deskripsi statistik mengenai skor terendah, skor tertinggi, rata-rata dan standar deviasi hasil pretest kedua kelas.

Tabel 1. Deskripsi Statistik Data Pretest Kemampuan Pemecahan Masalah Matematis

\begin{tabular}{cccccc}
\hline Kelas & $\begin{array}{c}\text { Skor } \\
\text { Ideal }\end{array}$ & $\begin{array}{c}\text { Skor } \\
\text { Terendah }\end{array}$ & $\begin{array}{c}\text { Skor } \\
\text { Tertinggi }\end{array}$ & $\begin{array}{c}\text { Rata- } \\
\text { Rata }\end{array}$ & $\begin{array}{c}\text { Standar } \\
\text { Deviasi }\end{array}$ \\
\hline Eksperimen & 12 & 5 & 10 & 7,50 & 1,437 \\
\hline Kontrol & 12 & 4 & 10 & 7,30 & 1,643
\end{tabular}

Berdasarkan Tabel 1, diperoleh rata-rata skor pretest kelas eksperimen adalah 7,50 dengan standar deviasi 1,437. Sedangkan untuk kelas kontrol diperoleh rata-rata 7,30 dengan standar deviasi 1,643. Dari deskripsi data tersebut terlihat bahwa kemampuan awal pemecahan masalah matematis kelas kontrol lebih baik daripada kelas eksperimen namun secara keseluruhan kemampuan kedua kelas tidak jauh berbeda. Untuk mengetahui sama 
atau tidaknya kemampuan pemecahan masalah matematis awal pada kedua kelas tersebut dilakukan analisis uji statistik kesamaan dua rata-rata independen. Sebelum dilakukan uji kesamaan dua rata-rata independen data pretest, terlebih dahulu dilakukan uji normalitas distribusi populasi dan homogenitas varians.

1) Uji Normalitas Distribusi Populasi

Uji normalitas distribusi populasi dilakukan untuk mengetahui apakah kedua kelas berasal dari populasi yang berdistribusi normal atau tidak. Adapun perumusan hipotesis untuk uji normalitas distribusi populasi data pretest adalah sebagai berikut.

$\mathrm{H}_{0}$ : Sampel berasal dari populasi yang berdistribusi normal.

$\mathrm{H}_{1}$ : Sampel berasal dari populasi yang tidak berdistribusi normal.

Uji normalitas distribusi populasi dilakukan dengan uji Shapiro Wilk menggunakan bantuan software SPSS versi 20.0. Kriteria pengujian dengan menggunakan taraf signifikansi 5\% adalah sebagai berikut:

a) jika nilai signifikansi (Sig.) $\geq 0,05$ maka $\mathrm{H}_{0}$ diterima.

b) jika nilai signifikansi (Sig.) $<0,05$ maka $\mathrm{H}_{0}$ ditolak.

Adapun hasil uji normalitas distribusi populasi data pretest disajikan dalam tabel di bawah ini.

Tabel 2. Hasil Uji Normalitas Distribusi Populasi Data Pretest

Kemampuan Pemecahan masalah matematis

Kelas Signifikansi Keterangan

\begin{tabular}{ccc}
\hline Eksperimen & 0,087 & Normal \\
\hline Kontrol & 0,151 & Normal \\
\hline
\end{tabular}

Dari hasil uji normalitas distribusi populasi yang terdapat pada Tabel 2, diperoleh nilai signifikansi untuk kelas eksperimen adalah 0,087, sedangkan nilai signifikansi untuk kelas kontrol adalah 0,151. Nilai tersebut lebih besar dari 0,05 sehingga dapat dikatakan bahwa sampel kelas eksperimen dan kelas kontrol berasal dari populasi yang berdistribusi normal.

2) Uji Homogenitas Varians

Uji homogenitas varians dilakukan untuk mengetahui apakah data dari kedua kelas berasal dari populasi yang memiliki varians yang homogen atau tidak. Adapun perumusan hipotesis untuk uji homogenitas varians data pretest adalah sebagai berikut.

$\mathrm{H}_{0}$ : Kedua varians populasi yang sampelnya diambil homogen.

$\mathrm{H}_{1}$ : Kedua varians populasi yang sampelnya diambil tidak homogen. 
Uji homogenitas varians dilakukan dengan uji Levene menggunakan bantuan software SPSS versi 20.0. Kriteria pengujian dengan menggunakan taraf signifikansi $5 \%$ adalah sebagai berikut:

a) jika nilai signifikansi (Sig.) $\geq 0,05$ maka $\mathrm{H}_{0}$ diterima.

b) jika nilai signifikansi (Sig.) $<0,05$ maka $\mathrm{H}_{0}$ ditolak.

Adapun hasil uji homogenitas varians data pretest disajikan dalam tabel di bawah ini.

Tabel 3. Hasil Uji Homogenitas Varians Data Pretest Kemampuan Pemecahan Masalah Matematis

\begin{tabular}{ccccc}
\hline Levene Statistic & df1 & df2 & Sig. & Keterangan \\
\hline $\mathbf{0 , 4 9 9}$ & 1 & 60 & 0,483 & Homogen \\
\hline
\end{tabular}

Dari hasil uji homogenitas varians yang terdapat pada Tabel 3, diperoleh nilai signifikansi 0,483. Nilai tersebut lebih besar dari 0,05 sehingga dapat disimpulkan bahwa data kedua kelas mempunyai variansi yang sama (homogen).

3) Uji Kesamaan Dua Rata-Rata Independen

Berdasarkan hasil pengujian normalitas dan homogenitas data pretest di atas diketahui bahwa sampel kelas eksperimen dan kelas kontrol berasal dari populasi yang berdistribusi normal serta kedua kelas tersebut mempunyai variansi yang homogen. Selanjutnya dilakukan pengujian kesamaan dua rata-rata independen menggunakan Independent-Sample T Test dengan bantuan software SPSS versi 20.0. Uji kesamaan dua rata-rata independen dilakukan untuk melihat apakah kedua kelas memiliki kemampuan pemecahan masalah matematis awal yang setara atau berbeda. Adapun perumusan hipotesis untuk uji kesamaan dua rata-rata independen adalah sebagai berikut.

$\mathrm{H}_{0}$ : Kedua kelas mempunyai kemampuan pemecahan masalah matematis awal yang setara.

$\mathrm{H}_{1}$ : Kedua kelas mempunyai kemampuan pemecahan masalah matematis awal yang berbeda.

Kriteria pengujian dengan menggunakan taraf signifikansi 5\% adalah sebagai berikut:

a) jika nilai signifikansi (Sig.) $\geq 0,05$ maka $\mathrm{H}_{0}$ diterima.

b) jika nilai signifikansi (Sig.) $<0,05$ maka $\mathrm{H}_{0}$ ditolak.

Adapun hasil uji kesamaan dua rata-rata independen data pretest disajikan dalam tabel di bawah ini.

Tabel 4. Hasil Uji Kesamaan Dua Rata-Rata Independen Data Pretest

$\begin{array}{cc}\text { Asymp.Sig. (2-tailed) } & \text { Keterangan } \\ \mathbf{0 , 6 1 1} & \mathrm{H}_{0} \text { diterima }\end{array}$


Dari hasil uji kesamaan dua rata-rata independen yang terdapat pada Tabel 4, diperoleh nilai signifikansi 0,611 . Nilai tersebut lebih besar dari 0,05 maka $\mathrm{H}_{0}$ diterima. Dengan demikian dapat disimpulkan bahwa kedua kelas mempunyai kemampuan pemecahan masalah matematis awal yang setara.

\section{Peningkatan Kemampuan Pemecahan Masalah Matematis Mahasiswa}

Analisis Indeks Gain dilakukan untuk mengetahui apakah terdapat perbedaan peningkatan kemampuan pemecahan masalah matematis antara kelas eksperimen dan kelas kontrol. Berikut ini disajikan deskripsi statistik mengenai skor terendah, skor tertinggi, rata-rata dan standar deviasi data hasil indeks gain pada kedua kelas.

Tabel 5. Deskripsi Statistik Data Indeks Gain Kemampuan Pemecahan Masalah Matematis

\begin{tabular}{cccccc}
\hline Kelas & $\begin{array}{c}\text { Jumlah } \\
\text { Mahasiswa }\end{array}$ & $\begin{array}{c}\text { Nilai } \\
\text { Terendah }\end{array}$ & $\begin{array}{c}\text { Nilai } \\
\text { Tertinggi }\end{array}$ & Rata-Rata & $\begin{array}{c}\text { Standar } \\
\text { Deviasi }\end{array}$ \\
\hline Eksperimen & 32 & 0,20 & 1,00 & 0,6449 & 0,2550 \\
\hline Kontrol & 30 & 0,13 & 0,50 & 0,2485 & 0,1144 \\
\hline
\end{tabular}

Berdasarkan Tabel 5, diperoleh rata-rata skor indeks gain kelas eksperimen adalah 0,6449 dengan standar deviasi 0,2550. Sedangkan untuk kelas kontrol diperoleh rata-rata 0,2485 dengan standar deviasi 0,1144. Dari deskripsi data tersebut terlihat bahwa skor ratarata kelas eksperimen lebih besar daripada skor rata-rata kelas kontrol. Namun, untuk mengetahui ada atau tidaknya perbedaan rata-rata peningkatan kemampuan pemecahan masalah matematis pada kedua kelas tersebut dilakukan analisis uji statistik perbedaan dua rata-rata independen. Sebelum dilakukan uji perbedaan dua rata-rata independen data indeks gain, terlebih dahulu dilakukan uji normalitas distribusi populasi dan homogenitas varians.

1) Uji Normalitas Distribusi Populasi

Uji normalitas distribusi populasi dilakukan untuk mengetahui apakah kedua kelas berasal dari populasi yang berdistribusi normal atau tidak. Adapun perumusan hipotesis untuk uji normalitas distribusi populasi data indeks gain adalah sebagai berikut.

$\mathrm{H}_{0}$ : Sampel indeks gain kedua kelas berasal dari populasi yang berdistribusi normal.

$\mathrm{H}_{1}$ : Sampel indeks gain kedua kelas berasal dari populasi yang tidak berdistribusi normal. 
Uji normalitas distribusi populasi dilakukan dengan uji Shapiro Wilk menggunakan bantuan software SPSS versi 20.0. Kriteria pengujian dengan menggunakan taraf signifikansi $5 \%$ adalah sebagai berikut:

a) jika nilai signifikansi (Sig.) $\geq 0,05$ maka $\mathrm{H}_{0}$ diterima.

b) jika nilai signifikansi (Sig.) $<0,05$ maka $\mathrm{H}_{0}$ ditolak.

Adapun hasil uji normalitas distribusi populasi data indeks gain disajikan dalam tabel di bawah ini.

Tabel 6. Hasil Uji Normalitas Distribusi Populasi Data Indeks Gain
\begin{tabular}{ccc} 
Kemampuan Pemecahan Masalah Matematis \\
\hline Kelas & Signifikansi & Keterangan \\
\hline Eksperimen & 0,007 & Tidak Normal \\
\hline Kontrol & 0,000 & Tidak Normal
\end{tabular}

Dari hasil uji normalitas distribusi populasi yang terdapat pada Tabel 6, diperoleh nilai signifikansi untuk kelas eksperimen adalah 0,007 dan untuk kelas kontrol adalah 0,000. Nilai tersebut lebih kecil dari 0,05 sehingga dapat disimpulkan bahwa sampel indeks gain kelas eksperimen dan kelas kontrol berasal dari populasi yang tidak berdistribusi normal.

2) Uji Perbedaan Dua Rata-Rata Independen

Berdasarkan hasil pengujian normalitas dan homogenitas data indeks gain di atas diketahui bahwa sampel kelas eksperimen dan kelas kontrol tidak berasal dari populasi yang berdistribusi normal dan. Maka untuk selanjutnya dilakukan pengujian perbedaan dua rata-rata independen menggunakan Mann Whitney U dengan bantuan software SPSS versi 20.0.

Uji perbedaan dua rata-rata independen dilakukan untuk melihat apakah kedua kelas memiliki peningkatan kemampuan pemecahan masalah matematis yang berbeda atau tidak. Adapun perumusan hipotesis untuk uji perbedan dua rata-rata independen adalah sebagai berikut.

$\mathrm{H}_{0}$ : Peningkatan kemampuan pemecahan masalah matematis mahasiswa yang menerapkan GeoGebra tidak lebih baik daripada mahasiswa dengan pembelajaran ekspositori.

$\mathrm{H}_{1}$ : Peningkatan kemampuan pemecahan masalah matematis mahasiswa yang menerapkan GeoGebra lebih baik daripada mahasiswa dengan pembelajaran ekspositori. 
Kriteria pengujian dengan menggunakan taraf signifikansi 5\% adalah sebagai berikut:

a) jika setengah nilai signifikansi $\geq 0,05$ maka $\mathrm{H}_{0}$ diterima.

b) jika setengah nilai signifikansi $<0,05$ maka $\mathrm{H}_{0}$ ditolak.

Adapun hasil uji perbedaan dua rata-rata independen data indeks gain disajikan dalam tabel di bawah ini.

Tabel 7. Hasil Uji Perbedaan Dua Rata-Rata Independen Data Indeks Gain Kemampuan Pemecahan Masalah Matematis

\begin{tabular}{cc}
\hline Asymp.Sig. (2-tailed) & Keterangan \\
\hline $\mathbf{0 , 0 0 0}$ & $\mathrm{H}_{0}$ ditolak
\end{tabular}

Dari hasil uji perbedaan dua rata-rata independen yang terdapat pada Tabel 7 , diperoleh setengah nilai signifikansi 0,000 . Nilai tersebut lebih kecil dari 0,05 maka $\mathrm{H}_{0}$ ditolak. Dengan demikian dapat disimpulkan bahwa peningkatan kemampuan pemecahan masalah matematis mahasiswa yang menerapkan GeoGebra lebih baik daripada mahasiswa dengan pembelajaran ekspositori.

Perbedaan peningkatan kemampuan pemecahan masalah matematis ini disebabkan karena perbedaan aktivitas dan suasana pembelajaran pada kelas eksperimen dan kelas kontrol. Pada kelas eksperimen pembelajaran dilakukan dengan menerapkan GeoGebra dimana mahasiswa lebih banyak mendapat pembendaharan soal, materi yang lebih luas, suasana pembelajaran yang menarik. Hal tersebut akan berpengaruh pada kemampuan mahasiswa untuk mencari dan menciptakan solusi untuk permasalahan yang sedang dihadapi. Sedangkan pada kelas kontrol pembelajaran dilakukan secara ekspositori, mahasiswa hanya mendapat materi dari dosen. Kesempatan mahasiswa untuk mengeksplor ide yang dimiliki kurang, oleh karena itu mahasiswa menjadi lebih kaku. Adapun faktor lain berasal dari kemampuan yang dimiliki atau kemampuan prasyarat. Kemampuan pemecahan masalah matematis dipengaruhi oleh beberapa kemampuan matematis lainnya seperti penalaran matematis dan lain lain. Seperti halnya bahwa terdapat hubungan positif dan signifikan antara kemampuan prasyarat dengan kemampuan penalaran matematis mahasiswa dalam mata kuliah Analisis Real (Septian ,2014).

\section{Sikap Mahasiswa terhadap Penerapan GeoGebra}

Angket skala sikap diberikan kepada mahasiswa di kelas eksperimen yaitu setelah pemberian perlakuan di kelas tersebut selesai. Tujuannya adalah untuk mengetahui sikap mahasiswa terhadap proses pembelajaran dengan menerapkan Geogebra. Angket tersebut berisi 20 pernyataan yang terdiri dari 13 pernyataan positif dan 7 pernyataan negatif. Dalam setiap pernyataan diberikan 5 pilihan yaitu: Sangat Setuju (S), Setuju (S), Netral 
(N), Tidak Setuju (TS), dan Sangat Tidak Setuju (STS). Pernyataan-pernyataan pada angket tersebut digolongkan ke dalam tiga indikator yaitu sikap mahasiswa terhadap mata kuliah matematika, sikap mahasiswa terhadap penerapan Geogebra, dan sikap mahasiswa terhadap kemampuan pemecahan masalah matematis.

Untuk mengetahui sikap mahasiswa terhadap penerapan GeoGebra digunakan perhitungan modus persentase pilihan jawaban mahasiswa yang telah dikelompokkan ke dalam 3 jenis sikap yaitu, sikap positif, sikap netral, dan sikap negatif. Berikut ini disajikan rekapitulasi hasil angket sikap mahasiswa.

Tabel 8. Persentase Total Sikap Mahasiswa terhadap Penerapan Geogebra Sikap Positif Sikap Netral Sikap Negatif Keterangan Sikap

\begin{tabular}{llll}
$\mathbf{7 0 , 5 0 \%}$ & $20,00 \%$ & $9,50 \%$ & Sebagian besar positif \\
\hline
\end{tabular}

Dari tabel 8 diperoleh modus persentase sikap mahasiswa sebesar 70,50\% yaitu pada sikap positif, maka dapat diartikan bahwa sebagian besar mahasiswa bersikap positif terhadap penerapan Geogebra.

Hal ini dapat disebabkan oleh adanya perubahan suasana belajar. Selama ini mahasiswa merasa jenuh dalam belajar dengan pembelajaran ekspositori, dimana mahasiswa hanya menerima materi atau informasi yang disampaikan oleh dosen, tetapi mahasiswa kurang diberi kesempatan untuk mencari solusi secara mandiri dan menyampaikan konsep-konsep matematika yang mereka miliki. Ketika mahasiswa mengikuti pembelajaran dengan menerapkan GeoGebra, mahasiswa merasa menemukan suasana belajar yang baru dan modern.

\section{KESIMPULAN}

Secara umum dapat dibuat kesimpulan hasil penelitian yaitu peningkatan kemampuan pemecahan masalah matematis mahasiswa yang menerapkan GeoGebra lebih baik daripada mahasiswa yang menggunakan pembelajaran ekspositori dan secara keseluruhan sikap mahasiswa terhadap penerapan GeoGebra adalah positif. 


\section{REFERENSI}

. (2014). What is GeoGebra. Tersedia: http://www.GeoGebra.org/cms/in/info. [23 Maret 2014].

Arikunto, S. (2009). Dasar-dasar Evaluasi Pendidikan.Jakarta : Bumi Aksara.

Arikunto, S. (2006). Prosedur Penelitian. Jakarta: Rineka Cipta.

National Council of Teacher of Mathematics. (2000). Principles and Standards for school Mathematics. Reston. VA:NCTM.

Sugiyono. (2007). Statistika untuk Penelitian. Bandung : Alfabeta.

Hohenwarter, M. \& Fuchs, K. (2004). Combination of Dynamic Geometry, Algebra, and Calculus in the Software System Geogebra. Tersedia: www.geogebra.org/publications/pecs_2004.pdf. [23 Maret 2014].

Pemerintah Republik Indonesia.(2003). Undang-Undang Republik Indonesia Nomor 20 Tahun 2003 Tentang Sistem Pendidikan Nasional. Jakarta.

Mahmudi, Ali. (2011). Pemanfaatan GeoGebra dalam Pembelajaran Matematika. Tesedia:

https://www.academia.edu/2137476/Pemanfaatan_GeoGebra_dalam_Pembelajaran _Matematika. [23 Maret 2014].

Septian, Ari. (2014). "Pengaruh Kemampuan Prasyarat terhadap Kemampuan Penalaran Matematis Mahasiswa dalam Matakuliah Analisis Real" in ATIKAN: Jurnal Kajian Pendidikan, Vol.4(2) December, pp.179-188. Bandung, Indonesia: Minda Masagi Press, FKIP UNSUR Cianjur, and FPOK UPI Bandung, ISSN 2088-1290. 